\title{
The Efficacy of Monetary Policy Variables in Reducing Unemployment Rate in Nigeria
}

\author{
D. Amassoma \\ Department of Economics and development studies \\ Federal university, Oye, Ekiti State, Nigeria \\ E-mail: amassoma.dit@gmail.com \\ Francis Oluwatosin Esther \\ Department of Economics and development studies \\ Federal university, Oye, Ekiti State, Nigeria
}

Received: Nov. 30, 2015

Accepted: Dec. 14, 2015

Published: Dec. 16, 2015

doi:10.5296/ifb.v2i2.8739

URL: http://dx.doi.org/10.5296/ifb. v2i2.8739

\begin{abstract}
The main purpose of embarking on this study is to ascertain the effectiveness of monetary policy in reducing unemployment rate in Nigeria using data spanning from 1970-2013. Despite the inconsistences in monetary policy instruments in Nigeria over the years there had not been much concrete evidence from theoretical and empirical literatures, regarding whether or not monetary policy is an effective tool that can be used to achieve key macroeconomic objective in the country vis-a-vis unemployment rate. The aforementioned as made this current study to be inevitable in terms of ascertaining whether monetary policy instrument in form of contractionary monetary policy exhibits the tendency to reduce unemployment rate in the country which is a topical issue around the globe. In order to achieve the above goals, the study utilized multiple regressions (OLS) approach and error correction modelling was used to examine the effect of some key monetary policy variables on unemployment in Nigeria. Evidence from the result shows that exchange rate and consumer's price index are the only monetary policy variables that influence unemployment rate while others do not. The results equally x-rayed that there is a unidirectional causality between monetary policy variable and unemployment rate which runs from exchange rate to unemployment. Owing from the above, the study therefore recommends that, the monetary authorities via central bank of Nigeria should ensure some reasonable monetary policy stands that would be suitable in reducing interest rate in the economy. Furthermore they should
\end{abstract}




\section{Macrothink}

International Finance and Banking ISSN 2374-2089 2015, Vol. 2, No. 2

ensure relatively stable prices of goods and services which would guarantee sustainable investment that can enhance employment opportunities in the country.

Keywords: monetary policy, error correction model, unemployment, Nigeria 


\section{Introduction}

Monetary policy has invariably been seen as an elementary instrument over the years for the attainment of macroeconomics stability, usually viewed as necessity to achieving sustainable growth. Thus, within the pursuit of macroeconomic stability, the managers of monetary policy have typically set targets on intermediate variables that embody the short term interest rate, growth of money supply and exchange rate. Among these intermediate variables of monetary policy, the exchange rate is argued to have a larger influence on the economy through its impact on the value of domestic currency, domestic inflation, the external sector, economics credibility, capital flows and money stability. Increased exchange rate directly affects values the costs of foreign commodities and a rise within the price of foreign merchandise and services contributes on to increase in inflation (CBN, 2008). Essentially the consequences of macroeconomic policy depend on the effective use of monetary policy on inevitable macroeconomic aggregates. It cannot be denied that the ability to achieve the staffed economic policy objectives such as non-inflationary growth, exchange rate stability, promoting financial sector soundness, mobilization and product use of resources, employment and output growth depend on the choice of appropriate mix of policy instruments.

The interest rates conjointly had a sway on the industries in no small part due to the marginal revolution in economic growth that shows however members of the general public would change a decision supported within the industrial trade-offs. Other instrument of monetary policy square measure the market rate of interest, the market rate of returns etc. In this research work, broad money supply, Treasury bill rate, consumer price index, monetary policy rate and exchange rate will be adopted to analyse the effect of monetary policy on unemployment in Nigeria. The term monetary policy is employed to explain the suggestion that a chief financial administrative body within a country tries to influence the flow of money among a specified economy through the initiation and promulgation of policies geared toward the overall stabilization of the economy. In this respect, reducing unemployment in the country would be one of the principal goals of the monetary authority, a task that is usually reserved for the central bank in that country. As such, the connection between monetary policy and unemployment is the undeniable fact that monetary policy is used as a method for the regulation of the economy, one thing that essentially involves the reduction of unemployment. To this end, monetary policy may either be an expansionary one or it is going to be crafted to be contractionary. Consequently, this link between monetary policy and unemployment is most apparent, due to the fact that expansionary monetary policy is specifically geared toward making unemployment rates to be kept at the barest minimum, particularly once the economy is or could presently be in an exceedingly recession.

A further associate degree analysis of the relationship between monetary policy and unemployment can reveal that one in all the monetary policies adopted by the apex bank inside an economy into account to lower the rates of unemployment could be a reduction of the interest rates. This is done by the regulatory bank with the intention that the reduced rate can have a ripple impact on the economy, eventually resulting in hiring employees and neglecting unemployment, particularly in an exceedingly recession. Usually, once the Apex 
bank reduces its interest rates, the other banks within the economy can function as a vehicle for the implementation of the monetary policy by conjointly reducing their own interest rates and relaxing some of their conditions for the approval of loans to people and businesses alike. This can be seen within the manner during which the interest rates connected to the acquisition and utilization of credit are reduced, creating it more likely that various businesses can have access to much-needed loans for expansion as well the maintenance and growth of the business.

The link between monetary policy and unemployment here is that the power of the companies to realize easier access to loan and credit facilities can function as a method for them not to solely continue their operations, but to also function as a room for expansion. Where this is often the case, such businesses would not have the cause to extend the speed of unemployment by shedding their employees in times of economic downturns. The contrary is that the aim within the applying associate expansionary financial policy since this can function as a method for the companies to not solely retain their staff, however to conjointly rent additional owing to a probable enlargement.

Despite the above, it is noticeable that the monetary policy enforced within the economy over the past years has been detrimental to and inconsistent with the departmental need of the economy as observed by (Apata, 2007). This concern has exerted pressures on the national monetary authorities in Nigeria to re-examine and re-evaluate their domestic monetary policies with the view of finding possible solutions. As a result of this, the Structural adjustment programme was introduced in Nigeria in 1986 so as to correct structural imbalances within the economy and to liberalize the national economy. In guaranteeing optimum growth in liquidity for meeting desired growth and balance of payment objectives and at a similar time come through economic stability. However despite all effort place in situation to boost and increase the amount of each national output (i.e. Gross Domestic Product) and employment in Nigeria, very little may be shown for the efforts that have been put in place by the government towards economic growth and development in African nations at large especially in Nigeria. Government through the monetary authority has been controlling the money supply in circulation to stop inflation and deflation within the economy, and maintain a balanced growth and development in Nigeria. Yet the distortion still exists. The main problems of this paper is based on the area of detecting the relationship between monetary policy and unemployment rate despite the increase in money supply and all other instruments of monetary policy in Nigeria. Therefore this research work will want to examine the effect of some key monetary variables like (Exchange Rate, Treasury bill, Broad Money Supply, Monetary Policy Rate, Consumers Price Index) on unemployment in Nigeria.

\section{Literature Review and Theoretical Framework}

\subsection{Theoretical Framework}

As a matter of fact, there are many theories that pinpoint to the relationship between monetary policy and unemployment level in Nigeria. For the sake of simplicity only few would be discussed here which includes; unemployment in the real business cycle theory, the Keynesian monetary policy and the monetarist view. 


\subsubsection{Unemployment in the Real Business Cycle Theory}

It is argued during this theory in line with Chatterjee (1995), that the expansion of productivity of input that revolutionizes technology is the main supply of employment and unemployment. The author expressed that if the expansion of output will increase over the expansion of inputs, then total issue productivity or the residual, has inflated. If total issue productivity is not growing, then corporations and also the economy become inefficient. It follows that reallocation of labour and capital cannot be achieved and labour and capital are employed in less profitable opportunities. There are varied causes for the lag in total issue productivity.

Technology is not up within the production of products and services and employees skills are not being increased. New merchandise are not fictional once the price of foreign materials is increasing. Once total issue productivity is stagnating, the co-movements in different vital variables can lag. For instance, consumption expenditures will not increase on top of the trend, nor can investment disbursement. Value and total hours worked will not be on top of the trend either. Once consumption, investment, GDP, and hours of labour decline, the Solow's residual, that represents the expansion burning productivity and is measured by the distinction between actual and foreseen productivity growth (or shocks), can decline. That is, there is no improvement in technology and productivity underneath this condition. Therefore, unemployment will increase. Technology stocks caused by scientific and engineering development, by R\&D, management techniques, and by industrial organizations that build inputs a lot of productive.

In Schumpeter's word innovations being introduced and terribly effective in creating the economy grow. Innovations and favourable technological shocks conjointly cut back inputs and increase total issue productivity. In short, if shocks to productivity led to technological shocks do not exit, unemployment will rise. Gali \& Rabanal (2004) contend that demand and monetary shocks have an effect on the variables of the trade cycle, together with employment, by regarding $75 \%$, where the technological shocks have an effect on those variables by regarding $25 \%$. For him, non-technology shocks generated positive movement between hours and productivity. His results were not according to the trade cycle theory.

\subsubsection{The Keynesian Monetary Policy}

The essential element of Keynesian economics is the idea that the macro economy can be in disequilibrium (recession) for a considerable time. Keynesian economics advocates government intervention to help overcome the lack of aggregate demand to reduce unemployment and increase growth. Keynes does not agree with the older quantity theorists that there is a direct and proportional relationship between quantity of money and prices. According to him, the effect of a change in the quantity of money on prices is indirect and non-proportional. Keynes complains that economics has been divided into two compartments with no doors or windows between the theory of value and the theory of money and prices. This dichotomy between the relative price level (as determined by demand and supply of goods) and the absolute price level (as determined by demand and supply of money) arises from the failure of the classical monetary economists to integrate value theory with monetary theory According to him, the problems of the real world are related to the theory of shifting 
equilibrium whereas money enters as a "link between the present and future". Keynes's Reformulated Quantity Theory of Money:

The Keynesian reformulated quantity theory of money is based on the following:

Assumptions:

- All factors of production are in perfectly elastic supply so long as there is any unemployment's.

- All unemployed factors are homogeneous, perfectly divisible and interchangeable.

- There are constant returns to scale so that prices do not rise or fall as output increases.

- Effective demand and quantity of money change in the same proportion so long as there are any unemployed resources.

Given these assumptions, the Keynesian chain of causation between changes within the amount of cash associated in costs is an indirect one through the speed of interest. Therefore once the amount of cash is exaggerated, its 1st impact is on the speed of interest that tends to fall. Given the marginal potency of capital, a fall within the rate of interest can increase the amount of investment. The exaggerated investment can raise resultant demand through the multiplier factor effect thereby increasing financial gain, output and employment. Since the provision curve of things of production is absolutely elastic in an exceedingly scenario of state, wage and non-wage factors are obtainable at constant rate of remuneration. There being constant returns to scale, costs does not rise with the rise in output as long as there is any unemployment. Below the circumstances, output and employment can increase within the same proportion as effective demand, and therefore the effective demand can increase within the same proportion with the quantity of money. But once full employment is reached, output ceases to retort the least bit to changes within the supply of money and then in effective demand.

The elasticity of supply of output in response to changes within the supply that was infinite as long as there was unemployment falls to zero. The whole result of changes within the supply of money is exerted on costs that rise in precise proportion with the rise in effective demand. So long as there is unemployment, output can change within the same proportion because the quantity of money, and there will be no change in prices; and once there is full employment, costs can change within the same proportion because of the quantity of money. Therefore, the reformulated amount theory of money stresses the purpose that with increase within the quantity of money costs rise only if the amount of full employment is reached, and not before this. Keynesian himself discovered that the important world is thus difficult that the simplifying assumptions, upon that the reformulated quantity theory of money relies, will not hold. In line with him, the subsequent potential complications would qualify the statement that as long as there is unemployment, employment can change within the same proportion because of the quantity of money, and once there is full employment, price can change within the same proportion because of the quantity of money according to Tily (1993). 


\subsubsection{The Monetarist View}

The monetarist view argues that solely financial matters in associate degree economic which economic recessions and expansions are caused by decrease and increase in funds severally. They emphasize that the expansion rate of money is that the principal determinant of the behaviour of national income. This view relies on variety of historical studies allotted by Friedman and Schwarz, Friedman and Meiselman, Anderson and Jordan of the FRS Bank of Saint Price fighter. These studies reveal that there is an awfully shut relationship between funds than between value and any of the economic expert variables like combination expenditure. Although the monetarists have tried to enforce their position on the idea of empirical studies nevertheless they are skeptical concerning the success of monetary policy in distinction of economic policy. They agree that as associate degree economic stabilizer, monetary policy could do a lot of damage than sensible attributable to the operational lag.

The operational lag refers to the time elapsing between taking of associate degree action and also the effective impact of that action on the economic state of affairs. On the common it takes long term for an amendment within the cash in hand to affects value thus additionally the operation lag. Milton Friedman himself admits that the intermission concerned is thus giant that contrary diurnal monetary policy may even have destabilizing result on the economy. The economist thus, hold that the economy is essentially stable and once disturbed by some changes in basic conditional can quickly revert to its end of the day growth path. It is on this basis that the monetarists advocate associate degree mounted proportion growth within the cash in hand and a finish to discretionary monetary policy. Milton Friedman thus, believes that economic policy might not have any potent influence on the economy except that it affects the behavior of money.

\subsection{Empirical Evidence}

Usman \& Adejare (2004) examined the impact of monetary policy on industrial growth in Nigeria economy covering the period of 1970-2010. They employed multiple regressions. Their result shows that monetary policy has significant effects on the industrial growth.

Danjuma, Jbrin \& Onyeiwu (2004) examined the impact of monetary policy on the Nigerian economy from 1981 to 2008 using the Ordinary Least Squares (OLS) Method. The result of the analysis shows that monetary policy presented by money supply exerts a positive impact on GDP growth and Balance of Payment but negative impact on rate of inflation.

Chuku (2009) observed the effect of monetary policy innovations in Nigeria. The study used a structural vector auto-regression (SVAR) approach to trace the effects of monetary policy shocks on output and prices in Nigeria with a sample data spanning from 1986 to 2008. The study conducted the experiment using three alternative policy instruments i.e. broad money (M2), Minimum Rediscount Rate (MRR) and the real effective exchange rate (REER). The study made the assumption that the Central Bank cannot observe unexpected changes in output and prices within the same period. This places a recursive restriction on the disturbances of the SVAR and helped to generate impulse response functions that tracked the effects of monetary policy innovations on output and prices. 
Muhammad (2011) researched into the role of unemployment on the making of the Nigerian Gross Domestic Product (GDP) for a period of nine years (2000-2008). His data was analysed using regression analysis, findings showed that unemployment has enormous effects on crime (over 65 percent) on the making of the Nigerian GDP and there exist an inverse relationship between the model (unemployment) and the GDP-increase in the model leads to decrease on the GDP and vice versa.

Blessing (2012) examined the impact of monetary policy on inflation in Nigeria covering the period from 1980-2010. The study employs classical least squares method. The result shows that the liquidity ratio and interest rate are the leading monetary policy instruments that can be employed to combat inflation in Nigeria.

Hammer \& Sturn (2012) inspected the impact of monetary policy on unemployment covering the year (1980-2007). The result shows that the extent to which hysteresis occurs in the aftermath of recessions depend on monetary policy reactions.

Gideon (2012) examined the impact of monetary policy reforms on output growth in Nigeria covering the period of 1986-2009. Using co-integration analysis and the ordinary least square (OLS) procedures, the result shows that monetary policy instrument have not been effective in stimulating the growth of output in Nigeria during the reform period.

Bakare (2012) scrutinized the implication of unemployment crisis on economic growth. Standard econometric method, Ordinary Least Square multiple regression, (OLS) to determine the relationship between urban unemployment crisis and economic growth. The results of his finding show that the past values of unemployment crisis could be used to predict the future behavior of economic growth.

Ahiabor (2013) surveyed the effect of monetary policy on inflation in Ghana using annual data from (1985-2009). The results show a long-run positive relationship between money supply and inflation, negative relationship between interest rate and inflation. However, his finding reveals a positive relationship between exchange rate and inflation. Furthermore, Fasanya, Onakoya \& Adegboluade (2013) studied the impact of monetary policy on economic growth in Nigeria. The study uses time-series data covering the range of (1975-2010). Using Error Correction Model (ECM) technique the study result shows that Long run relationship exists among the variables. Also, the core finding of the study shows that inflation rate, exchange rate and external reserve are significant monetary policy instruments that drive growth in Nigeria.

Furthermore, Amassoma \& Nwosa (2013) examined the relationship between unemployment rate and productivity growth in Nigeria for the period 1986 to 2010. The study utilized co-integration and error correction model approach. Findings of the study posited that there is still the need for government to take urgent steps against the rising unemployment rate, because unemployment is a major impediment to social progress and results in waste of trained manpower.

Emirgena \& Nikolli (2014) observed the relationship between the economic growth and the unemployment rate in Albania. This relation is known as Okun's law, which states that 1 
percent decrease in unemployment; GDP will increase by 3 percent during recession there is a high unemployment rate covering the period of 2000 to 2013. The methodology used a simple regression and takes the economic growth as dependent variable and the unemployment rate as independent. The observed result explain the Okun's law for Albania. The main reason is the current crises that prevent the improvement of economic conditions.

\subsection{Other Factors that Affects Unemployment other than Monetary Policy Variables}

This study further wants to emphasize or state that there are some other factors that can affect unemployment rate in Nigeria other than monetary policy variables. These variables among others include:

i. Nigeria as a member WTO (World Trade Organization) can kind of diminish the rate of unemployment to a huge degree that is by joining and taking after the stipulated propositions of the organization as pinpointed by Kiasi \& Amiri Aghdaie (2013). Moreover, the authors figure out that participation in WTO and taking after the proposals with the expectation of complimentary exchanging would expand openings for work and abatement of unemployment for the most part.

ii. Another factor that tends to influence unemployment rate is the demand conditions. This demand conditions has a critical part to play in affecting export and production of goods and services. This was corroborated in the study of Amiri Aghdaie et al. (2012) where they opine that changing the demand condition can possibly build deals and production which thus can eventually lessen unemployment rate.

iii. Furthermore, the next element that can influence unemployment rate other than monetary policy variable is the coordination of supply chain management technologies and expanding the investment in supply chain can decrease unemployment rate in Nigeria. No wonder, Riasi (2015) observed that expanding investment in supply chain and incorporating supply chain monument technologies can help induce production and distribution, which swing prompts lower unemployment rate likewise.

\section{Methodology and Model Specification}

\subsection{Model Specification}

In this paper unemployment will be used as the dependent variable, while exchange rate, monetary policy rate, Treasury bill and broad money supply will be used as independent variables. In order to develop a model that will explain the effect of monetary policy on unemployment in Nigeria, the model of the form will be formulated which is adopted by Chimezie (2008) as stated below:

Specifically, the functional form of the model is as below:

$$
\mathrm{UNE}=\mathrm{f}(\mathrm{TBILL}, \mathrm{M} 2, \mathrm{MRR}, \mathrm{EXCHR}, \mathrm{CPI}, \mathrm{MPR})
$$

where: 
$\mathrm{UNE}=$ Unemployment rate

TBILL $=$ Treasury bill rate

M2 = Broad money supply

$\mathrm{EXCHR}=$ Exchange rate

$\mathrm{MPR}=$ Monetary policy rate

$\mathrm{CPI}=$ Consumer Price Index

Assuming a linear relationship between the dependent variable and independent variables, the equation using the multiple regression analysis econometrically, the equation could be stated as follows:

$$
U N E-\beta_{0}+\beta_{1} M z+\beta_{2} T E R+\beta_{2} E X C H R+\beta_{4} M P E+\beta_{5} C P I+\mu
$$

Given that the estimation is a time series analysis, we incorporate the time factor thus

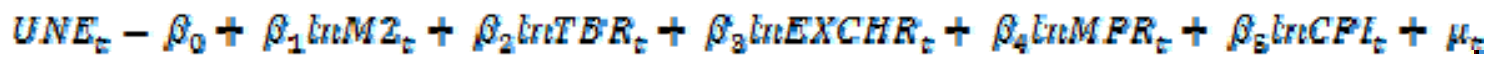

where $\mu_{\mathrm{t}}=$ Error term

Given that time series data could be affected as a result of changes in trend, this model will be transformed into a linear-logarithms form of the above model is specified as follows:

$$
U N E_{t}=\beta_{0}+\beta_{1} \ln T B I L L_{t}+\beta_{2} \ln M 2_{t}+\beta_{3} \ln M R R_{t}+\beta_{4} \ln E X C H R_{t}+\beta_{5} \ln C P I_{t}+\beta_{6} \ln M P R_{t}+\mu_{t}
$$

It is equation (4) that would be estimated in the following section.

\subsection{Sources of Data}

The researcher utilizes the data generated from the Central Bank of Nigeria statistical bulletin on exchange rate, minimum rediscount rate, Treasury bill broad money supply from 1970 -2013. Also, data on unemployment Rate from the CBN statistics was employed. It should equally be noted the dataset obtained are in their annual form. This is because the annual data of these data are the ones that are readily available from CBN database and that of the Bureau of Statistical Bulletin from various editions.

\section{Data Analysis and Discussion of Results}

The analysis begins with the descriptive statistics which will enable us to explore the time series properties of the variables. The descriptive statistics employed in the study are the summary of statistics, normality test and correlation matrix

\subsection{Descriptive Statistics}

The descriptive statistics of the variables is provided in table 1 below. From the table, the 
averages of the variables are 49.07, 1.43, 11.70, 10.85, 10.25 and 7.69 for exchange rate (EXR), consumer price index (LCPI), money supply (LM2), and monetary policy rate (MPR), Treasury bill rate (TBR) and unemployment rate (UNE) respectively. The maximum values of the variables are 157.50,4.91, 16.53, 26.0, 26.9 and 23.9 for exchange rate (EXR), consumer price index (LCPI), money supply (LM2), monetary policy rate (MPR), treasury bill rate (TBR) and unemployment rate (UNE) respectively while the minimum values of the variables are $0.55,-2.30,6.67,3.5,2.5$ and 1.8 for exchange rate (EXR), consumer price index (LCPI), money supply (LM2), monetary policy rate (MPR), treasury bill rate (TBR) and unemployment rate (UNE) respectively. The standard deviation showed that exchange rate (61.03) was the most volatile variable in the time series. This is followed by Treasury bill rate (5.73), unemployment rate (5.43), monetary policy rate (5.19) and money supply (3.01) while consumer price index (-2.30) was the least volatile of the time series. The skewness statistic from table below revealed that with exception to consumer price index (LCPI) which was negatively skewed, the other remaining variables (exchange rate, money supply, monetary policy rate, Treasury bill rate and unemployment rate) were positively skewed. The kurtosis statistics showed that exchange rate (EXR), consumer price index (LCPI) and money supply (LM2) were platykurtic, suggesting that their distributions were flat relative to normal distribution while unemployment rate (UNE) is leptokurtic, suggesting that the distribution is peaked relative to normal distribution. Also, the kurtosis statistics showed that monetary policy rate (MPR) and Treasury bill rate (TBR) are normally distributed. Lastly, the Jarque-Bera statistic rejected the null hypothesis of normal distribution for unemployment rate (UNE) at five percent critical value while the null hypothesis of normal distribution for the other variables (exchange rate, consumer price index, money supply, monetary policy rate and Treasury bill rate) were accepted at the same critical value.

Table 1. Descriptive statistics

\begin{tabular}{|c|c|c|c|c|c|c|}
\hline Variables & EXR & LCPI & LM2 & MPR & TBR & UNE \\
\hline Mean & 49.068 & 1.430 & 11.702 & 10.851 & 10.251 & 7.669 \\
\hline Median & 13.604 & 1.196 & 11.424 & 11.000 & 9.525 & 5.250 \\
\hline Maximum & 157.499 & 4.905 & 16.534 & 26.000 & 26.900 & 23.900 \\
\hline Minimum & 0.546 & -2.303 & 6.671 & 3.500 & 2.500 & 1.800 \\
\hline Std. Dev. & 61.026 & 2.442 & 3.008 & 5.188 & 5.725 & 5.428 \\
\hline Skewness & 0.736 & -0.050 & 0.048 & 0.492 & 0.627 & 1.262 \\
\hline Kurtosis & 1.726 & 1.473 & 1.827 & 2.932 & 2.914 & 3.859 \\
\hline Jarque-Bera & 6.951 & 4.294 & 2.542 & 1.786 & 2.895 & 13.038 \\
\hline Probability & 0.031 & 0.117 & 0.281 & 0.409 & 0.235 & 0.001 \\
\hline Observations & 44 & 44 & 44 & 44 & 44 & 44 \\
\hline
\end{tabular}

Source: Authors computation (2015). 


\subsection{Unit Root Test}

Following the descriptive statistics of the variables, the time series properties of the variables was conducted by employing the Augmented Dickey-Fuller Test (ADF) and the result presented in table 2. The Augmented Dickey Fuller (ADF) test showed that all the variables were integrated of order one; that is, the variables became stationary after first difference.

Table 2. Unit root test result

\begin{tabular}{|c|c|c|c|}
\hline \multicolumn{4}{|c|}{ Augmented Dickey-Fuller (ADF) Test } \\
\hline Variables & Level & $1^{\text {st }}$ Diff & Status \\
\hline EXR & 0.3989 & $-6.0117^{*}$ & $\mathrm{I}(1)$ \\
\hline LM2 & -0.7288 & $-3.4604^{* *}$ & $\mathrm{I}(1)$ \\
\hline MPR & -2.2260 & $-6.8563^{*}$ & $\mathrm{I}(1)$ \\
\hline TBR & -2.2872 & $-7.1715^{*}$ & $\mathrm{I}(1)$ \\
\hline UNE & -2.0615 & $-5.9225^{*}$ & $\mathrm{I}(1)$ \\
\hline LCPI & -0.6392 & $-3.3767^{* *}$ & $\mathrm{I}(1)$ \\
\hline
\end{tabular}

Note. $*=1 \%$ and $* *=5 \%$ significance level.

Source: Authors computation (2015).

\subsection{Co-Integration Estimate}

The result of the co-integration estimate is presented in Table 3 below. From Table 3, it is observed that the null hypothesis of no co-integration, for $\mathrm{r}=0$ was rejected by both the trace and the maximum Eigen-value statistic. The statistical values of these tests were greater than their critical values. However, the null hypothesis of no co-integration that is $r \leq 1$ could not be rejected by the trace and maximum Eigen-value statistics because their statistical values were less than their critical values. The implication of the co-integration estimate is that there is one co-integrating equation at five percent in the model.

Table 3. Summary of the co-integration estimate

\begin{tabular}{|c|c|c|c|c|c|c|c|}
\hline \multicolumn{3}{|c|}{ Trace Test } & \multicolumn{4}{c|}{ Maximum Eigen value Test } \\
\hline Null & Alternative & Statistics & $95 \%$ critical values & Null & Alternative & Statistics & $95 \%$ critical values \\
\hline $\mathrm{r}=0$ & $\mathrm{r} \geq 1$ & 105.998 & 95.754 & $\mathrm{r}=0$ & $\mathrm{r}=1$ & 41.126 & 40.076 \\
\hline $\mathrm{r} \leq 1$ & $\mathrm{r} \geq 2$ & 64.873 & 69.818 & $\mathrm{r} \leq 1$ & $\mathrm{r}=2$ & 25.155 & 33.877 \\
\hline $\mathrm{r} \leq 2$ & $\mathrm{r} \geq 3$ & 39.718 & 47.856 & $\mathrm{r} \leq 2$ & $\mathrm{r}=3$ & 18.258 & 27.584 \\
\hline $\mathrm{r} \leq 3$ & $\mathrm{r} \geq 4$ & 21.460 & 29.797 & $\mathrm{r} \leq 3$ & $\mathrm{r}=4$ & 14.607 & 21.132 \\
\hline
\end{tabular}

Source: Authors computation (2015) 
4.4 Long Run Regression Estimate on the Effect of Monetary Policy on Unemployment Rate in Nigeria

The long run regression estimate of the impact of monetary policy on unemployment rate in Nigeria for the period spanning 1970 to 2013 is presented on table 4 below. The coefficient of determination (that is $\mathrm{R}^{2}$ ) showed that the explanatory variables jointly explained about 71 percent of variations in unemployment rate in Nigeria during the study period. The F-statistics $(18.38 ; \mathrm{p}=0.000)$ showed that the model estimated is appropriate while the Durbin Watson statistics is 1.89 which is approximately 2.0 , there by indicating the absence of serial auto-correlation in the long run estimate. The long run estimate presented on table 4 below showed that exchange rate had a positive (0.078) and significant impact on unemployment rate in Nigeria, suggesting that a one percent increase in exchange rate will increase the rate of unemployment by about 7.8 percent. With respect money supply (LM2), monetary policy rate (MPR) and treasury bill rate (TBR), the regression estimate showed that the co-efficient of these variables were insignificant, suggesting that money supply (LM2), monetary policy rate (MPR) and treasury bill rate (TBR) have no significant effect on unemployment rate in Nigeria during the period 1970 to 2013. Finally, and in contrast to the above, the regression estimate showed that consumer price index (LCPI) had a negative (-2.69) and significant impact at $10 \%$ critical level on unemployment rate, suggesting that a one percent increase in consumer price index will decrease the level of unemployment by about $26.9 \%$. With respect to the focus of this current study, on the effect of monetary policy on unemployment rate, the regression estimate showed that only exchange rate and consumer price index had significant effect on unemployment rate in Nigeria while the remaining variables were insignificant in influencing the level of unemployment in Nigeria in the long run.

Table 4. Long run regression estimate

\begin{tabular}{|c|c|c|c|c|}
\hline Variable & Coefficient & Std. Error & t-Statistic & Prob. \\
\hline EXR & 0.078403 & 0.020216 & 3.878219 & 0.0004 \\
\hline LM2 & 1.981921 & 1.248352 & 1.587630 & 0.1207 \\
\hline MPR & -0.248740 & 0.272627 & -0.912385 & 0.3673 \\
\hline TBR & 0.070010 & 0.222465 & 0.314703 & 0.7547 \\
\hline LCPI & -2.691937 & 1.529540 & -1.759965 & 0.0865 \\
\hline C & -13.53905 & 12.77258 & -1.060009 & 0.2958 \\
\hline R-squared & 0.707517 & Mean dependent var & 7.669318 \\
\hline Adjusted R-squared & 0.669032 & S.D. dependent var & 5.428299 \\
\hline S.E. of regression & 3.122890 & Akaike info criterion & 5.241518 \\
\hline Sum squared resid & 370.5927 & Schwarz criterion & 5.484817 \\
\hline Log likelihood & -109.3134 & \multicolumn{2}{|c|}{ Hannan-Quinn criter. } & 5.331745 \\
\hline F-statistic & 18.38440 & \multicolumn{2}{|c|}{ Durbin-Watson stat } & 1.196489 \\
\hline Prob(F-statistic) & 0.000000 & \multicolumn{3}{|}{} \\
\hline
\end{tabular}

Source: Authors computation (2015). 
4.5 Short Run Regression Estimate on the Impact of Monetary Policy on Unemployment Rate in Nigeria

The short run relationship among unemployment rate and monetary policy variables is examined below. Prior to the short run regression estimate, the stationarity property of the residual from the long run estimate is examined and the result is presented on table 5 below. Using the Augmented Dickey Fuller (ADF) test, the stationarity test showed that the residual is integrated of order one at five percent significant level.

Table 5. Residual stationarity test

\begin{tabular}{|c|c|c|}
\hline Variable & ADF Test & Order of Integration \\
\hline Resid & $-4.2453^{*}$ & $\mathrm{I}(0)$ \\
\hline
\end{tabular}

Note. * implies $1 \%$ significance level.

Source: Authors computation (2015).

With respect to the parsimonious regression estimate capturing the short run analysis, it is observed from table 6 that there are significant improvement in the parsimonious model of the over parameterized model (See Appendix). The coefficient of determination (that is $\mathrm{R}^{2}$ ) from the short estimate showed that the explanatory variables jointly explained about 66 percent of variations in unemployment rate in Nigeria in the short run. The F-statistics (6.57; $\mathrm{p}<0.000$ ) showed that the model estimated is appropriate while the Durbin Watson statistics is 2.10 , indicating the absence of serial auto-correlation in the long run estimate. The short run regression estimate also showed that the coefficient of the error-term for the ECM model is both statistically significant at one percent and negative. The coefficient estimate of the error correction term of -1.62 implied that the model corrects its short run disequilibrium by about 162 percent speed of adjustment in order to return to the long run equilibrium. Also, the negative sign of the error correction term indicates a move back towards equilibrium. In addition to the above, it was observed that the co-efficient of the first lagged value of unemployment rate $(\triangle \mathrm{UNE}(-1))$ was positive $(0.85)$ and significant at one percent significant level, suggesting that a one percent increase in the immediate past value of unemployment rate will increase current rate of unemployment rate by about 85 percent. In contrast, the coefficient of the second lagged value of unemployment rate $(\triangle \mathrm{UNE}(-2))$ and the first lagged value of money supply $(\triangle \mathrm{LM} 2(-1))$ were insignificant in influencing current value of unemployment in the short run. Also, the short run regression estimate presented on table 6 showed that current value of monetary policy rate $(\triangle \mathrm{MPR})$ had negative $(-0.87)$ and significant effect on unemployment rate at one percent significant level in the short run, thereby indicating that a one percent decrease in the current value of monetary policy rate will increase unemployment rate by about 87 percent. In contrast to the effect of monetary policy rate on unemployment rate in the short run, it was observed that current value of treasury bill rate $(\triangle \mathrm{TBR})$ had positive $(0.63)$ and significant effect on unemployment rate at 
one percent significant level, thereby indicating that a one percent increase in the current value of treasury bill rate will increase unemployment rate by about 63 percent.

Table 6. Parsimonious short run regression estimate

\begin{tabular}{|c|c|c|c|c|}
\hline Variable & Coefficient & Std. Error & t-Statistic & Prob. \\
\hline $\mathrm{C}$ & 2.290680 & 1.084916 & 2.111389 & 0.0429 \\
\hline $\operatorname{ECM}(-1)$ & -1.618497 & 0.257730 & -6.279808 & 0.0000 \\
\hline$\triangle \mathrm{UNE}(-1)$ & 0.846631 & 0.193264 & 4.380703 & 0.0001 \\
\hline$\Delta \mathrm{UNE}(-2)$ & 0.365058 & 0.186049 & 1.962155 & 0.0588 \\
\hline$\Delta \mathrm{LM} 2(-1)$ & -6.432804 & 4.223397 & -1.523135 & 0.1379 \\
\hline$\Delta \mathrm{MPR}$ & -0.874140 & 0.244801 & -3.570812 & 0.0012 \\
\hline$\Delta \mathrm{TBR}$ & 0.634417 & 0.205493 & 3.087293 & 0.0042 \\
\hline$\Delta \mathrm{LCPI}$ & -5.384741 & 3.672972 & -1.466045 & 0.1527 \\
\hline$\Delta \mathrm{LCPI}(-1)$ & 10.06731 & 4.615177 & 2.181349 & 0.0369 \\
\hline$\Delta \mathrm{LCPI}(-2)$ & -8.039440 & 3.967434 & -2.026358 & 0.0514 \\
\hline R-squared & 0.656241 & \multicolumn{2}{|c|}{ Mean dependent var } & -0.007317 \\
\hline Adjusted R-squared & 0.556440 & \multicolumn{2}{|c|}{ S.D. dependent var } & 3.433789 \\
\hline S.E. of regression & 2.286914 & \multicolumn{2}{|c|}{ Akaike info criterion } & 4.700504 \\
\hline Sum squared resid & 162.1293 & \multicolumn{2}{|c|}{ Schwarz criterion } & 5.118448 \\
\hline Log likelihood & -86.36033 & \multicolumn{2}{|c|}{ Hannan-Qunncriter. } & 4.852696 \\
\hline F-statistic & 6.575495 & \multicolumn{2}{|c|}{ Durbin-Watson stat } & 2.101741 \\
\hline Prob (F-statistic) & 0.000034 & & & \\
\hline
\end{tabular}

With respect to the short run effect of consumer price index on unemployment rate in the short run, it was observed from the short run regression estimate on table 6 that the current $(\triangle \mathrm{LCPI})$ and second lagged values of consumer price index $(\Delta \mathrm{LCPI}(-2))$ with the coefficient values of the -5.38 and -8.04 respectively, had negative but insignificant effect on unemployment rate in the short run. However, the first lagged value of consumer price index $(\Delta \mathrm{LCPI}(-1))$ had positive (10.07) and significant impact on unemployment rate in the short run, suggesting that a one percent increase in the first lagged value of consumer price index, will increase the rate of unemployment rate by about 10.1 percent in the short run.

With respect to the objective of this study, it was observed from the discussion on the short run analysis that only current values of monetary policy rate and treasury bill rate and also the first lagged value of consumer price index that influence unemployment rate in the short run.

\subsection{Causality Estimate}

With respect to the nature of causality between unemployment rate and monetary policy variables, this study employed the pairwise granger causality test. The result of the causality estimate is present in table 7 below. From the table, it is observed that there is a unidirectional 
causality from consumer price index to exchange rate while no causality exists from exchange rate to consumer price index. This indicates that changes in consumer price index cause changes in exchange rate. Also, the study observed that there is a unidirectional causality from exchange rate to unemployment rate while no causality was observed from unemployment rate to exchange rate. This implies that changes in exchange rate influences changes in unemployment rate and not otherwise.

Table 7. Pairwise granger causality tests

\begin{tabular}{|c|c|c|}
\hline Null Hypothesis: & F-Statistic & Prob. \\
\hline LCPI does not Granger Cause EXR & 5.42216 & 0.0086 \\
\hline EXR does not Granger Cause LCPI & 0.29292 & 0.7478 \\
\hline LM2 does not Granger Cause EXR & 2.53410 & 0.0930 \\
\hline EXR does not Granger Cause LM2 & 0.46052 & 0.6345 \\
\hline MPR does not Granger Cause EXR & 0.53865 & 0.5880 \\
\hline EXR does not Granger Cause MPR & 0.27323 & 0.7624 \\
\hline TBR does not Granger Cause EXR & 0.22119 & 0.8026 \\
\hline EXR does not Granger Cause TBR & 0.06379 & 0.9383 \\
\hline UNE does not Granger Cause EXR & 0.77392 & 0.4685 \\
\hline EXR does not Granger Cause UNE & 6.17656 & 0.0048 \\
\hline LM2 does not Granger Cause LCPI & 1.92526 & 0.1602 \\
\hline LCPI does not Granger Cause LM2 & 3.49124 & 0.0408 \\
\hline MPR does not Granger Cause LCPI & 4.46719 & 0.0183 \\
\hline LCPI does not Granger Cause MPR & 0.36251 & 0.6984 \\
\hline TBR does not Granger Cause LCPI & 4.92518 & 0.0127 \\
\hline LCPI does not Granger Cause TBR & 0.49180 & 0.6155 \\
\hline UNE does not Granger Cause LCPI & 0.29342 & 0.7474 \\
\hline LCPI does not Granger Cause UNE & 1.87997 & 0.1669 \\
\hline MPR does not Granger Cause LM2 & 0.97951 & 0.3850 \\
\hline LM2 does not Granger Cause MPR & 0.15252 & 0.8591 \\
\hline TBR does not Granger Cause LM2 & 0.54908 & 0.5821 \\
\hline LM2 does not Granger Cause TBR & 0.40823 & 0.6678 \\
\hline UNE does not Granger Cause LM2 & 0.78475 & 0.4637 \\
\hline LM2 does not Granger Cause UNE & 1.47884 & 0.2411 \\
\hline TBR does not Granger Cause MPR & 3.15850 & 0.0541 \\
\hline MPR does not Granger Cause TBR & 5.39033 & 0.0088 \\
\hline UNE does not Granger Cause MPR & 0.03874 & 0.9620 \\
\hline MPR does not Granger Cause UNE & 0.24924 & 0.7807 \\
\hline UNE does not Granger Cause TBR & 0.58935 & 0.5598 \\
\hline TBR does not Granger Cause UNE & 0.50519 & 0.6075 \\
\hline
\end{tabular}


Unidirectional causality was also observed from consumer price index to broad money supply while no causality was observed from broad money supply to consumer price index; suggesting that changes in consumer price index cause changes in broad money supply and not otherwise. Furthermore, unidirectional causality was also observed from monetary policy rate to consumer price index while no causality was observed from consumer price index to monetary policy rate; suggesting that changes in monetary policy rate causes changes in consumer price index and not otherwise. Also, unidirectional causality was also observed from treasury bill rate to consumer price index while no causality was observed from consumer price index to treasury bill rate; suggesting that changes in treasury bill rate causes changes in consumer price index and not otherwise.

However, bi-directional causality was observed between monetary policy rate and treasury bill rate, suggesting that changes in monetary policy rate cause changes in treasury bill rate while changes in treasury bill rate also causes changes in monetary policy rate. With respect to the other pairs of variable in table 7 , no causal relationship was observed. Therefore, with respect to the objective of this study on the nature of causality between unemployment rate and monetary policy variables, the findings from the pairwise causality estimate, showed that only changes in exchange rate influences changes in unemployment rate, other monetary policy variables did not granger cause unemployment rate while unemployment rate did not also granger cause other monetary policy variables.

\section{Conclusion and Recommendation}

\subsection{Conclusion}

This study examines the effect of monetary policy on unemployment in Nigeria covering the period 1970-2013. Multiple regression analysis was employed in the analysis to the data gathered with the aid of E-views on the model consisting M2, TBILL, EXCHR, MPR, and CPI as the exogenous variables while unemployment is the endogenous variable. The study concludes that only exchange rate and consumer's price index are monetary variables that influence unemployment rate. Based on the causality estimate the study concludes that with that only changes in exchange rate influences changes in unemployment rate, other monetary policy variables did not granger cause unemployment rate while unemployment rate did not also granger cause other monetary policy variables.

\subsection{Recommendation and Policy Implication}

From the observation and subsequent problems discussed in the study, the following recommendations are proffered as thus.

a. The monetary authorities should ensure reasonable monetary policy stand that will be suitable to reduce interest rate in an economy. For example if government reduce interest rate it will give investors an opportunity to get contracts which will increase the number of labourers, this will brings about increase in employment thereby decreasing unemployment.

b. The monetary authorities should also made Exchange Rate stable to ensure that unemployment don't rise. 
c. They should also ensure price stability that will ensure sustainable investment that can enhance employment opportunities.

\section{References}

Abel, A. B. (2008). Macroeconomics (6th ed., pp. 34-78). Wharton school of university of Pennsylvania.

Amassoma, D., \& Nwosa, P. I. (2013). The impact of unemployment rate on productivity growth in Nigeria. International journal of economics and management science, 2(8), 1-13.

Amiri Aghdaie, S. F., Seidi, M., \& Riasi, A. (2012). Identifying the barriers to Iran's Saffron Export by Using Porter's Diamond Model. International Journal of Marketing Studies, 4(5), 129-138. 10.5539/ijms, v4n5p129

Christiano, L. J., Trabandt, M., \& Walentin, K. (2011). Introducing Financial Frictions and Unemployment into a Small Open Economy Model. Journal of Economic Dynamics and Control, 35, 1999-2041. 10.1016/j.jedc

Carlin, W., \& Soskice, D. (1990). Macroeconomics and the Wage Bargain: A Modern Approach to Employment Inflation and the Exchange Rate. Oxford: Oxford University Press.

Central Bank of Nigeria. (2008). Annual Report and Statement of Central Bank of Nigeria Bullion, 32(2).

Ezeduji, F. O. (1994). Conduct of Monetary Management in Nigeria. Onitsha: Wema Publishers.

Folawewo, A. O., \& Osinubi, T. S. (2006). Monetary Policy and Macro-Economic Stability in Nigeria. A Rational Expectation Approach, Journal of Social Science, 12(2), 93-100.

Gujarati, D. N. (2003). Basic Economics. New York: Hill Companies.

Jaeger, A., \& Parkinson, M. (1994). Some evidence on hysteresis in unemployment rates. European Economic Review, 38, 32-42. http://dx.doi.org/10.1016/0014-2921(94)90061-2

Jimoh, I. (1991). Monetary Policy in Nigeria in the 1980 and Prospects. Lagos: Inner Ways Publishers.

Kogiku, K. C. (1968). The National Rate of Unemployment. Explanation and policy Article, 122(2), 161-166.

Kakes, J. (2000). Monetary transmission and business cycle asymmetry. Credit and capital, 33, 18-97.

Kuzin, V., \& Tober, S. (2004). Asymmetric monetary policy effects in Germany. DIW Berlin Discussion Paper No. 397.

Koutsoyiannis, G. (2001). The Theory of Econometrics (2nd ed.). London: Macmillan Press.

Lavoie, M. (2006). A post-Keynesian amendment to the new consensus on monetary policy. Metro economical, 57, 16-92. http://dx.doi.org/10.1111/j.1467-999X.2006.00238.x 


\section{Macrothink}

Million, F. C. (1971). A Monetary Theory of Income. Journal of Political Economy, 21, 2-13.

Mishkin, F. S. (2004). Can inflation targeting work in emerging market countries? National Bureau of Economic Research. Working Paper Series No. 10646.

Nkoro, E. (2003). Analysis of Impact of Monetary Policy on Economic Development in Nigeria (1980-2000). Department of Accountancy Edo, University of Benin Nigeria Press. An unpublished BSc project.

Ojo, M. O. (1992). The Evolution and Performance of Monetary Policyin Nigeria in the 1980's. Owerri: Spring Field. Publishers Limited.

Ocampo, J. A. (2005). A broad view of macroeconomic stability. United Nations. Department of Economics and Social Affairs. [Online] Available: http://ideas.repec.org/p/une/wpaper/1.html

Phillips, A. W. (1958). The relationship between unemployment and the rate of change of Money Wage Rate. Article first published online: 26 March 2007. Economica, 25(100), 283-299.

Riasi, A. (2015). Barriers to international supply chain management in Iranian flower industry. Management Science Letters, 5 (4), 363-368. http://dx.doi.org/10.5267/j.msl.2015.2.005

Tunde, L. (2004). Evaluation of monetary policy. Central Bank of Nigeria, Monetary policy review, 1(1).

Tily, G. (2009). John Maynard Keynes and the development of national accounts in Britain, 1895 to 1941. Review of income and wealth, 55(2), 33-59. http://dx.doi.org/10.1111/j.1471-8847.2009.00322.x

Turner \& Philip. (2011). Is the long-term interest rate a policy victim, a policy variable or a PolicyLodestar? BIS Working Papers No 367. December. [Online] Available: http://www.bis.org/publ/work367.htm

\section{Appendix}


Over-Parametized Short Run Regression Estimate

\begin{tabular}{|c|c|c|c|c|}
\hline Variable & Coefficient & Std. Error & $\mathrm{t}$-Statistic & Prob. \\
\hline $\mathrm{C}$ & 1.542750 & 1.631275 & 0.945733 & 0.3546 \\
\hline $\operatorname{ECM}(-1)$ & -1.717964 & 0.412323 & -4.166548 & 0.0004 \\
\hline DUNE(-1) & 0.859423 & 0.313078 & 2.745079 & 0.0118 \\
\hline DUNE(-2) & 0.386875 & 0.256546 & 1.508015 & 0.1458 \\
\hline DEXR & 0.018258 & 0.037693 & 0.484395 & 0.6329 \\
\hline $\operatorname{DEXR}(-1)$ & -0.014107 & 0.047801 & -0.295129 & 0.7707 \\
\hline $\operatorname{DEXR}(-2)$ & 0.003258 & 0.043073 & 0.075637 & 0.9404 \\
\hline DLM2 & 3.636654 & 5.263716 & 0.690891 & 0.4969 \\
\hline DLM2(-1) & -9.719024 & 6.616070 & -1.469003 & 0.1560 \\
\hline DLM2(-2) & 2.286227 & 5.289272 & 0.432239 & 0.6698 \\
\hline DMPR & -0.991020 & 0.326332 & -3.036843 & 0.0061 \\
\hline $\operatorname{DMPR}(-1)$ & -0.125978 & 0.374707 & -0.336203 & 0.7399 \\
\hline $\operatorname{DMPR}(-2)$ & -0.060177 & 0.366653 & -0.164125 & 0.8711 \\
\hline DTBR & 0.735712 & 0.280515 & 2.622713 & 0.0155 \\
\hline DTBR(-1) & 0.166826 & 0.311050 & 0.536332 & 0.5971 \\
\hline DTBR(-2) & 0.124318 & 0.312297 & 0.398077 & 0.6944 \\
\hline DLCPI & -6.570815 & 4.940207 & -1.330069 & 0.1971 \\
\hline DLCPI(-1) & 12.17677 & 6.380051 & 1.908569 & 0.0695 \\
\hline DLCPI(-2) & -8.635521 & 5.127968 & -1.684004 & 0.1063 \\
\hline R-squared & 0.679413 & \multicolumn{2}{|c|}{ Mean dependent var } & -0.007317 \\
\hline Adjusted R-squared & 0.417114 & \multicolumn{2}{|c|}{ S.D. dependent var } & 3.433789 \\
\hline S.E. of regression & 2.621594 & \multicolumn{2}{|c|}{ Akaike info criterion } & 5.069742 \\
\hline Sum squared resid & 151.2006 & \multicolumn{2}{|c|}{ Schwarz criterion } & 5.863836 \\
\hline Log likelihood & -84.92971 & \multicolumn{2}{|c|}{ Hannan-Quinn criter. } & 5.358907 \\
\hline F-statistic & 2.590226 & \multicolumn{2}{|c|}{ Durbin-Watson stat } & 1.949738 \\
\hline Prob (F-statistic) & 0.017832 & & & \\
\hline
\end{tabular}

\section{Copyright Disclaimer}

Copyright for this article is retained by the author(s), with first publication rights granted to the journal.

This is an open-access article distributed under the terms and conditions of the Creative Commons Attribution license (http://creativecommons.org/licenses/by/3.0/). 